raised to $90^{\circ} \mathrm{C}$., and by maintaining these conditions for five to six hours the yield of monoalkyl sulphates is increased by hydrolysis of the di-alkyl sulphates. After the batch has been cooled, the emulsion is broken by the addition of weak isopropanol. Two layers form, the upper consisting of unreacted oil and alcohol, the lower of an alcoholic solution of sodium alkyl sulphates with unreacted mineral oil and excess alkali. The upper layer is redistilled for the recovery of alcohol, while the oil is returned to the refinery for processing to diesel oil. The alcoholic detergent layer is freed from mineral oil by washing with suitable solvent spirit, after which it is concentrated and freed from alcohol and solvent spirit (which has replaced the unreacted oil), and finally lesves the evaporators as a syrupy liquid.

The Conference was well attended, and there were lively discussions on some of the papers. It is apparent that there is widespread appreciation of the importance of the oil shales and related materials as potential sources of oil, and much experimental and pioneering work is being carried out on the production and refining of shale oil. There seems, however, to be comparatively little work in progress on the more fundamental aspects of the chemical composition and constitution of the oil shales; therefore there is a lack of balance in the picture as presented by the Conference.

\section{THE VETERINARY PROFESSION IN INDIA}

TN his presidential address to the tenth All-India Veterinary Congress held last April in Bombay, Dr. S. Datta, director of the Indian Veterinary Research Institute, Mulkteswar, appealed for the creation of an Indian veterinary council, which should be a statutory body set up by Act of Parliament, with power to enforce a high standard of veterinary education in Indian veterinary colleges, to suppress quackery in the veterinary profession and to co-ordinate the work of the various State veterinary departments. Dr. Datta also urged the creation of an all-India veterinary association with affiliated State associations, the function of which would be to look after the interests of Indian veterinarians.

The reasons why India needs a higher standard of veterinary education and a better co-ordination of veterinarians and their work were discussed in the course of Dr. Datta's address. He deplored the lack of interest shown by the State and the public in the welfare and improvement of farm stock, and rightly urged that veterinarians should not merely wait until disease occurs and then try to remove or prevent it. Directing special attention to the importance of Indian cattle, he said that agriculture in India is really dependent upon animal husbandry, because farm animals in India are often the only source of power for agricultural work and they supply, in dry areas, the motive power for land-irrigation; they are the mainstay of transport in agricultural areas and the chief source of manure. Assessing the individual values of transport, manure, hides, milk and milk products, eggs and wool, Dr. Datta estimated that the income derived directly and indirectly from farm stock represents two-thirds of the Indian national income. Apart from the control of the preventable diseases which cause heavy losses, there is urgent need for the establishment of good pastures, the preservation of grasses as hay or silage, the utilization of slaughterhouse waste, and the preparation and distribution of processed livestock foods. But these are only short-term measures ; they cannot succeed unless scientific systems of breeding are also established, by means of which the number of animals can be reduced and their productivity increased.

Urging State participation in this policy, Dr. Datta regretted that at present the State spends on veterinary projects and animal husbandry only 0.08 per cent of the total budget grants. He described a programme for the development of disease control and animal husbandry and discussed the lack of properly educated veterinarians. India has only 10 veterinarians per million head of livestock, whereas Great Britain has 95 and Switzerland 248. India, said Dr. Datta, requires developments in veterinary education equal to those which have occurred in Britain and other countries. Although new Indian veterinary colleges have been established and a better scientific education is being given, the men who are giving this education have been drawn from the Mukteswar Institute, and the demand for leaders of this kind is now greater than the supply. The existing plans for the enlargement and reorganisation of the veterinary profession upon which the supply of leaders depends should therefore not be held up any longer, and an Indian veterinary council is required.

Dr. Datta's views will be supported by everyone who is interested in the welfare of India, whether they see the future of this great country from the outside, or have been, until recently, quietly laying the foundations upon which the reorganisation outlined by Dr. Datta could be brought into being. Quite apart from political or economic considerations, this reorganisation and development is urgently required for the sake of the farm animals themselves.

G. LAPAGE

\section{EVOLUTION IN BACTERIA AND THE SIGNIFICANCE OF THE BACTERIAL SPORE}

\author{
By DR. K. A. BISSET
}

Department of Bacteriology, University of Birmingham

$T$ HE tendency of most groups of living creatures to evolve from a condition in which structure and function, and especially the reproductive and distributive functions, are adapted to an aquatic existence, to a terrestrial form, is clearly discernible in bacteria.

Purely aquatic bacteria ane of three main types, of which one is free-swimming and two are sessile. The free-swimming bacteria are more or less spiral in form, much more so than the truly terrestrial bacteria. The sessile bacteria may be stalked (caulobacteria) or filamentous (chlamydobacteria), or, in some cases, both. Thus bacteria may make use of, or resist, the distributive potentialities of the water.

Bacteria of many other types are found in water but some are unquestionably there by accident, and only the spiral and sessile forms appear to be specific. ally adapted to an aquatic existence. 